\title{
Kajian Daya Tampung Sungai Citarik Provinsi Jawa Barat
}

\author{
Eka Wardhani dan Lina Apriyanti Sulistiowati \\ Jurusan Teknik Lingkungan, Fakultas Teknik Sipil dan Perencanaan, ITENAS Bandung \\ Jalan PH.H. Mustofa No. 23 Bandung, Jawa Barat 40124 \\ Email: ekw_wardhani@yahoo.com
}

\begin{abstract}
ABSTRAK
Kajian perhitungan daya tampung Sungai Citarik diharapkan menjadi data/informasi yang diperlukan dalam menganalisis kebijakan pengelolaan kualitas air dan pengendalian pencemaran air. Sungai Citarik merupakan sungai lintas kabupaten. Maksud dilaksanakannya penelitian ini yaitu mendapatkan data gambaran hasil perhitungan tampung beban pencemaran untuk parameter BOD dan COD. Tujuan dilaksanakannya penelitian ini adalah: mendapatkan angka DTBP (daya tampung beban pencemaran) Sungai Citarik; memperoleh angka jumlah beban pencemar yang harus dikurangi dari masing-masing sumber pencemar agar kualitas air Sungai Citarik memenuhi kelas air yang ditetapkan DTBP nya; dan mencari berbagai pilihan kebijakan untuk menurunkan beban pencemaran dan dampaknya. Berdasarkan hasil perhitungan daya tampung beban pencemaran Sungai Citarik di DAS Citarik yang berada di 3 kabupaten yaitu Kabupaten Bandung, Sumedang, dan Garut menunjukkan bahwa kualitas air Sungai Citarik telah tercemar hal ini terlihat dari beberapa parameter seperti: TDS, TSS, BOD, COD, DO, Nitrat, Krom heksavalen, Tembaga, Nitrit, Klorin Bebas, Sulfida, Detergen MBAS, Total Colli dan Fecal Coli yang tidak memenuhi baku mutu. Ditinjau dari status mutu air Sungai Citarik termasuk katagori tercemar sedang sampai dengan berat. Kehadiran beberapa jenis logam berat di Sungai Citarik harus diwaspadai mengingat sifat dari logam yang, persistent, toksik, dan bersifat bioakumulasi.Berdasarkan hasil perhitungan terlihat bahwa daya tampung beban pencemaran air Sungai Citarik untuk parameter BOD dan COD sudah jauh terlampaui.
\end{abstract}

Kata Kunci: Sungai Citarik, Daya Tampung, Beban Pencemaran

\begin{abstract}
The Citarik River capacity calculation study is expected to be the data / information needed in analyzing water quality management and water pollution control policies. Citarik River is a crossdistrict river. The purpose of this research is to obtain the image of the calculation result of load pollution load for BOD and COD parameters. The purpose of this research is to obtain DTBP number (pollution load capacity) of Citarik River; obtain the number of polluted loads to be reduced from each pollutant source so that the water quality of the Citarik River meets the water class set by its DTBP; and look for policy options to reduce pollution loads and their impacts. Based on the calculation of pollution load capacity of Citarik River in Citarik River Basin located in 3 regencies of Bandung, Sumedang, and Garut Regency shows that the water quality of Citarik River has been polluted this can be seen from several parameters such as: TDS, TSS, BOD, COD, DO, Nitrates, Chromium hexavalent, Copper, Nitrite, Chlorine Free, Sulfide, MBAS Detergent, Total Colli and Fecal Coli that do not meet the quality standard. Viewed from the status of Citarik River water quality including the category of moderate to severe pollution. The presence of some heavy metals in the Citarik River should be cautioned given the nature of the metal that is, persistent, toxic, and bioaccumulative. Based on the calculation results show that the water pollution load capacity of Citarik River for BOD and COD parameters is far exceeded.
\end{abstract}

Key Words: Citarik River, Capacity, Pollution Load 


\section{PENDAHULUAN}

Kajian perhitungan daya tampung Sungai Citarik diharapkan menjadi data/informasi yang diperlukan dalam menganalisis kebijakan pengelolaan kualitas air dan pengendalian pencemaran air. Daya tampung beban pencemaran ini digunakan sebagai dasar dalam pemberian izin lokasi, pengelolaan air dan sumber air, penetapan rencana tata ruang, pemberian izin pembuangan air limbah dan penetapan mutu air sasaran serta program kerja pengendalian pencemaran air.

Sungai Citarik merupakan sungai lintas kabupaten, DAS Citarik yang berada di 3 kabupaten dan 11 kecamatan antara lain Kabupaten Bandung meliputi 7 kecamatan antara lain Kecamatan Solokan Jeruk, Kecamatan Cikancung, Kecamatan Cicalengka, Kecamatan Paseh, Kecamatan Rancaekek, Kecamatan Nagreg dan Kecamatan Majalaya, Kabupaten Sumedang meliputi 4 kecamatan antara lain Kecamatan Jatinangor, Kecamatan Tanjungsari, dan Kecamatan Cimanggung serta Kabupaten Garut dengan Kecamatan Blubur Limbangan [1].

Maksud dilaksanakannya penelitian ini yaitu mendapatkan data gambaran hasil perhitungan tampung beban pencemaran untuk parameter BOD dan COD di Sungai Citarik yang mencakup 3 kabupaten yang berada di Kabupaten Bandung, Kabupaten Sumedang dan Kabupeten Garut. Tujuan dilaksanakannya penelitian ini adalah: mendapatkan angka DTBP (daya tampung beban pencemaran) Sungai Citarik; memperoleh angka jumlah beban pencemar yang harus dikurangi dari masing-masing sumber pencemar agar kualitas air Sungai Citarik memenuhi kelas air yang ditetapkan DTBP nya; dan mencari berbagai pilihan kebijakan untuk menurunkan beban pencemaran dan dampaknya.

Ruang lingkup penelitian perhitungan daya tampung Sungai Citarik terdiri dari lingkup lokasi dan lingkup kegiatan. Lingkup lokasi p di laksanakan di Sungai Citarik termasuk Sub-DAS Citarik yang berada di 3 kabupaten dan 11 kecamatan. Kabupaten Bandung meliputi 7 kecamatan antara lain Kecamatan Solokan Jeruk, Cikancung, Cicalengka, Paseh, Rancaekek, Nagreg dan Majalaya. Kabupaten Sumedang meliputi 3 kecamatan antara lain Kecamatan Jatinangor, Tanjungsari, dan Cimanggung, serta Kabupaten Garut dengan Kecamatan Blubur Limbangan. Lingkup materi pada penelitian ini adalah melakukan pengumpulan, perhitungan, rekapitulasi dan analisis beban pencemar di Sungai Citarik pada lokasi yang telah ditentukan mewakili sungai Citarik bagian hulu, tengah, dan hilir.

\section{METODE PENELITIAN}

Lokasi penelitian dilakukan di 5 tempat yang mewakili Sungai Citarik bagian hulu, tengah, dan hilir seperti disajikan pada Tabel 1 .

Tabel 1. Lokasi Pengambilan Sampling DAS Citarik

\begin{tabular}{|c|c|c|c|c|}
\hline \multirow{3}{*}{ No } & \multirow{3}{*}{ Lokasi } & \multirow{2}{*}{\multicolumn{2}{|c|}{ Koordinat }} & \multirow{3}{*}{ Keterangan } \\
\hline & & & & \\
\hline & & $\mathbf{S}$ & $\mathbf{E}$ & \\
\hline 1 & Wisata Aki Enin & '06’57'56,8 & $107^{\prime} 51^{\prime} 58,1$ & Sungai Citarik bagian hulu \\
\hline 2 & Mesjid AL Asstro & '06’58’01,5 & $107^{\prime} 49^{\prime} 48,0$ & Sungai Citarik bagian tengah \\
\hline 3 & Haur Pugur & '06’58'55,5 & $107^{\prime} 48 ’ 10,9$ & Sungai Citarik bagian tengah \\
\hline 4 & Jembatan Citarik II & '06’59’48,0 & $107^{\prime} 44^{\prime} 52,1$ & Sungai Citarik bagian hilir \\
\hline 5 & Jembatan Sapan-Citarik & ‘06’59’17,0 & $107^{\prime} 42 ’ 20,0$ & $\begin{array}{c}\text { Sungai Citarik bagian hilir sebelum masuk } \\
\text { Sungai Citarum }\end{array}$ \\
\hline
\end{tabular}

Penelitian ini bekerjasama dengan Dinas Lingkungan Hidup Provinsi Jawa Barat. Parameter yang diuji sebanyak 26 parameter yang terdiri dari 2 parameter Fisika, 22 parameter Kimia, dan 2 parameter mikrobiologi. Tabel 2 menjabarkan secara rinci metode yang dipergunakan untuk menganalisis kualitas air sungai di Sungai. Seluruh kualitas air yang dipantau dibandingkan dengan baku mutu berdasarkan Peraturan Pemerintah Nomor 82 Tahun 2001 tentang Pengelolaan Kualitas Air dan Pengendalian Pencemaran Air [2] untuk kelas II yaitu prasaran/sarana rekreasi air, pembudidayaan ikan air tawar, peternakan, pertanaman, dan peruntukkan lain dengan syarat kualitas yang sama. 
Tabel 2. Parameter dan Metode Pengujian Kualitas Air Sungai [2]

\begin{tabular}{|c|c|c|c|}
\hline No & Parameter & Satuan & Metode \\
\hline & \multicolumn{3}{|l|}{ FISIKA } \\
\hline 1 & Padatan Terlarut Total (TDS) & $\mathrm{mg} / \mathrm{L}$ & SNI 06-6989.27-2005 \\
\hline \multirow[t]{2}{*}{2} & Padatan Tersuspensi Total (TSS) & $\mathrm{mg} / \mathrm{L}$ & SNI 06-6989.3-2004 \\
\hline & \multicolumn{3}{|l|}{ KIMIA } \\
\hline 1 & $\mathrm{pH}$ & - & SNI 06-6989.11-2004 \\
\hline 2 & $\mathrm{BOD}_{5}$ & $\mathrm{mg} / \mathrm{L}$ & SNI 6989.72:2009 \\
\hline 3 & COD & $\mathrm{mg} / \mathrm{L}$ & SNI 6989.2:2009 \\
\hline 4 & Total Fosfat Sebagai P & $\mathrm{mg} / \mathrm{L}$ & APHA 4500 P-D-2012 \\
\hline 5 & Nitrat $\left(\mathrm{NO}_{3}-\mathrm{N}\right)$ & $\mathrm{mg} / \mathrm{L}$ & SNI 6989.79:2011 \\
\hline 6 & $\operatorname{Arsen}(\mathrm{As})^{*}$ & $\mathrm{mg} / \mathrm{L}$ & APHA 3114-C-2012 \\
\hline 7 & Kobal (Co)* & $\mathrm{mg} / \mathrm{L}$ & SNI 6989.68:2009 \\
\hline 8 & Boron $(\mathrm{B})^{*}$ & $\mathrm{mg} / \mathrm{L}$ & US EPA Methode No 200.7-2001 \\
\hline 9 & Selenium $(\mathrm{Se})^{*}$ & $\mathrm{mg} / \mathrm{L}$ & APHA 3114-C-2012 \\
\hline 10 & $\operatorname{Kadmium}(\mathrm{Cd})^{*}$ & $\mathrm{mg} / \mathrm{L}$ & SNI 6989.16:2009 \\
\hline 11 & Krom Heksavalen $\left(\mathrm{Cr}^{6+}\right)$ & $\mathrm{mg} / \mathrm{L}$ & SNI 6989.71:2009 \\
\hline 12 & Tembaga $(\mathrm{Cu})^{*}$ & $\mathrm{mg} / \mathrm{L}$ & SNI 6989.6:2009 \\
\hline 13 & Timbal $(\mathrm{Pb})^{*}$ & $\mathrm{mg} / \mathrm{L}$ & SNI 6989.8:2009 \\
\hline 14 & Air Raksa $(\mathrm{Hg})^{*}$ & $\mathrm{mg} / \mathrm{L}$ & SNI 6989.78:2009 \\
\hline 15 & Seng $(\mathrm{Zn})^{*}$ & $\mathrm{mg} / \mathrm{L}$ & SNI 6989.7:2009 \\
\hline 16 & Sianida $\left(\mathrm{CN}^{-}\right)$ & $\mathrm{mg} / \mathrm{L}$ & SNI 689.77-2011 \\
\hline 17 & Nitrit $\left(\mathrm{NO}_{2}-\mathrm{N}\right)$ & $\mathrm{mg} / \mathrm{L}$ & SNI 06-6989.9-2004 \\
\hline 18 & Klorin Bebas $\left(\mathrm{Cl}_{2}\right)$ & $\mathrm{mg} / \mathrm{L}$ & Colometri \\
\hline 19 & Belerang Bebas $\left(\mathrm{H}_{2} \mathrm{~S}\right)$ & $\mathrm{mg} / \mathrm{L}$ & SNI 6989.70:2009 \\
\hline 20 & Minyak dan Lemak & $\mathrm{mg} / \mathrm{L}$ & SNI 6989.10:2011 \\
\hline 21 & Detergen (MBAS) & $\mathrm{mg} / \mathrm{L}$ & SNI 06-6989.51-2005 \\
\hline \multirow[t]{2}{*}{22} & Fenol & $\mathrm{mg} / \mathrm{L}$ & SNI 06-6989.21-2004 \\
\hline & \multicolumn{3}{|l|}{ MIKROBIOLOGI } \\
\hline 1 & Fecal Coliform & Jumlah/100 mL & SM $9221 \mathrm{E}^{*}$ \\
\hline 2 & Coliform & Jumlah/100 mL & SM $9221 B^{*}$ \\
\hline
\end{tabular}

Pengukuran debit air sungai dilakukan pada saat yang bersamaan ketika pengambilan contoh air sungai. Pengukuran kecepatan aliran air sungai dilakukan dengan metode sesuai dengan SNI seperti yang disajikan dalam Tabel 3 .

Tabel 3. Metode Pengukuran Debit Sungai

\section{Metode}

Alat ukur arus tip

baling-baling

(Currentmeter)

\section{Nomor SNI}

03-2819-1992

\section{Cara satu titik, cara dua titik, dan} cara tiga titik. Pembacaan tinggi muka air dari papan duga dan pengikatannya terhadap titik tetap di lokasi. Rumus yang digunakan untuk menghitung kecepatan aliran tiap titik, kecepatan aliran rata-rata jalur vertikal, debit, tinggi muka air air rata-rata

\section{Syarat Lokasi}

- Tepat pada pos duga air

- Alur sungai harus lurus

- Distribusi garis aliran merata

- Aliran tidak terganggu

- Tidak terpengaruh pasang surut

- Tidak terpengaruh aliran lahar

\subsection{Penetapan Status Mutu Air Sungai Menggunakan Metode Indeks Pencemaran (IP)}

Indeks pencemaran (Pollution Index) yang digunakan untuk menentukan tingkat pencemaran relatif terhadap paremeter kualitas air yang diizinkan dihitung dengan mengacu kepada KepMenLH No. 115 tahun 2003 [3]. Prosedur penggunaan IP, jika $\mathrm{L}_{\mathrm{ij}}$ menyatakan konsentrasi parameter kualitas air yang dicantumkan dalam baku mutu suatu peruntukan air (j), dan $C_{i}$ menyatakan konsentrasi parameter kualitas air (i) yang diperoleh dari hasil analisis cuplikan air pada suatu lokasi pengambilan cuplikan 
dari suatu alur sungai, maka $\mathrm{PI}_{\mathrm{j}}$ adalah IP bagi peruntukan $(\mathrm{j})$ yang merupakan fungsi dari $\mathrm{C}_{\mathrm{i}} / \mathrm{L}_{\mathrm{ij}}$. Harga $\mathrm{P}_{\mathrm{ij}}$ ini dapat ditentukan dengan cara [3]:

1. Pilih parameter-parameter uang jika harga parameter rendah maka kualitas air akan membaik.

2. Pilih konsentrasi parameter bakumutu yang tidak memiliki rentang.

3. Hitung harga $\mathrm{C}_{\mathrm{i}} / \mathrm{L}_{\mathrm{ij}}$ untuk tiap parameter pada setiap lokasi pengambilan cuplikan.

a. Jika nilai konsentrasi parameter yang menurun meyatakan tingkat pencemaran meningkat, misal DO. Tentukan nilai teoritik atau nilai maksimum $\mathrm{C}_{\mathrm{im}}$ (missal untuk DO, maka $\mathrm{C}_{\mathrm{im}}$ merupakan nilai DO jenuh). Dalam kasus ini nilai $C_{i} / L_{i j}$ hasil pengukuran digantikan oleh nilai $C_{i} / L_{i j}$ hasil perhitungan, yaitu:

$$
\left(\mathrm{C}_{\mathrm{i}} / \mathrm{L}_{\mathrm{ij}}\right)_{\text {baru }}=\frac{C_{i m}-C_{i} \text { hasilpengukuran }}{C_{i m}-L_{i j}}
$$

b. Jika nilai baku $\mathrm{L}_{\mathrm{ij}}$ memiliki rentang

- untuk $\mathrm{C}_{\mathrm{i}} \leq \mathrm{L}_{\mathrm{i}}$ rata - rata

- $\left.\quad \mathrm{C}_{\mathrm{i}} / \mathrm{L}_{\mathrm{ij}}\right)_{\text {baru }}=\frac{\left.\left[C_{i}-L_{i j}\right) \text { rata }- \text { rata }\right]}{\left\{\left(L_{i j}\right) \text { minimum- }\left(L_{i j}\right) \text { rata }- \text { rata }\right.}$

- untuk $\mathrm{C}_{\mathrm{i}}>\mathrm{L}_{\mathrm{i}}$ rata - rata

- $\quad\left(\mathrm{C}_{\mathrm{i}} / \mathrm{L}_{\mathrm{ij}}\right)_{\text {baru }}=\frac{\left[C_{i}-\left(L_{i j}\right) \text { rata-rata }\right]}{\left\{\left(L_{i j}\right) \text { maksimum- }\left(L_{i j}\right) \text { rata-rata }\right.}$

c. keraguan timbul jika dua nilai $\left(\mathrm{C}_{\mathrm{i}} / \mathrm{L}_{\mathrm{ij}}\right)$ berdekatan dengan nilai acuan 1,0 , missal $\mathrm{C}_{1} / \mathrm{L}_{1 \mathrm{j}}=0,9$ dan $\mathrm{C}_{2} / \mathrm{L}_{2 \mathrm{j}}=1,1$ atau perbedaan yang sangat besar, misal $\mathrm{C}_{3} / \mathrm{L}_{3 \mathrm{j}}=5,0$ dan $\mathrm{C}_{4} / \mathrm{L}_{4 \mathrm{j}}=10,0$. Dalam contoh ini tingkat kerusakan badan air sulit ditentukan. Cara untuk mengetasi kesulitan ini adalah:

- penggunaan nilai $\left(\mathrm{C}_{\mathrm{i}} / \mathrm{L}_{\mathrm{ij}}\right)$ hasil pengukuran kalau nilai ini lebih kecil dari 1,0.

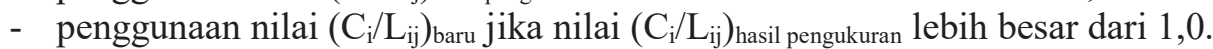

4. Tentukan nilai rata-rata dan nilai maksimum dari keseluruhan $\mathrm{C}_{\mathrm{i}} / \mathrm{L}_{\mathrm{ij}}\left(\left(\mathrm{C}_{\mathrm{i}} / \mathrm{L}_{\mathrm{ij}}\right)_{\mathrm{R}}\right.$ dan $\left.\left(\mathrm{C}_{\mathrm{i}} / \mathrm{L}_{\mathrm{ij}}\right)_{\mathrm{M}}\right)$.

5. tentukan harga $\mathrm{PI}_{\mathrm{j}}$

$$
\mathrm{PI}_{\mathrm{j}}=\sqrt{\frac{\left(C_{i} / L_{i j}\right)_{M}^{2}+\left(C_{i} / L_{i j}\right)_{R}^{2}}{2}}
$$

Perhitungan Daya Tampung Beban Pencemar Air (DTBPA) Sungai Citarik dilakukan perhitungan dengan rumus sebagai berikut [4]:

$\mathrm{DTBPA}=\mathrm{BPM}-\mathrm{BPA}$

Beban Pencemar Maksimum dihitung berdasarkan Q minimum sungai dan kadar sesuai dengan baku mutu air kelas II. Beban pencemar maksimum dihitung dengan rumus sebagai berikut:

$\mathrm{BPM}_{\mathrm{i}}=\mathrm{Q} \times \mathrm{C}_{\mathrm{i}}$

Beban Pencemar Aktual (BPA) DAS Cipalih merupakan beban pencemar hasil pengukuran dihitung dengan rumus sebagai berikut:

$\mathrm{BPA}_{\mathrm{i}}=\mathrm{Q} \times \mathrm{C}_{\mathrm{i}}$

Dimana: DTBPA yaitu daya tampung beban pencemar air (kg/hari), BPM yaitu beban pencemar maksimum (kg/hari), dan BPA adalah beban pencemar aktual (kg/hari). BPM $\mathrm{B}_{\mathrm{i}}$ adalah beban pencemar maksimum parameter i $(\mathrm{kg} / \mathrm{hari}), \mathrm{BPA}_{\mathrm{i}}$ adalah beban pencemar aktual parameter i $(\mathrm{kg} / \mathrm{hari}), \mathrm{Q}$ adalah Debit sungai $\left(\mathrm{m}^{3} /\right.$ detik), dan $\mathrm{C}$ adalah konsentrasi parameter I $(\mathrm{mg} / \mathrm{L})$. 


\subsection{Gambaran Umum Sungai Citarik}

\section{HASIL PEMBAHASAN}

Dilihat dari letak geografisnya Sub DAS Citarik diantara $6^{\circ} 57^{\prime}-7^{\circ} 14^{\prime}$ Lintang Selatan dan $107^{\circ} 24^{\prime}$ $107^{\circ} 37^{\prime}$ Bujur Timur. Berdasarkan topografinya sebagian besar wilayahnya masuk di Kabupaten Bandung dan sisanya masuk ke wilayah Kabupaten Sumedang dan Kabupaten Garut serta merupakan pegunungan atau daerah perbukitan dengan ketinggian di atas permukaan laut bervariasi dari 500$1.800 \mathrm{~m}$. Beberapa desa terletak ditepian hutan, tetapi sebagian besar berada di luar kawasan hutan. Sub DAS Citarik yang terletak di sebagian Kabupaten Bandung, Sumedang dan Garut beriklim tropis, dicirikan dengan adanya musim kemarau selama bulan Juni-September serta musim penghujan berlangsung pada Suhu udara harian dan tahunan berkisar antara $24^{\circ}-28^{\circ} \mathrm{C}$, kelembaban nisbi rata-rata tahunan sekitar $80 \%$.

Berdasarkan data yang di dapat terlihat pada Tabel 4 bahwa penggunaan lahan pertanian sawah terbesar terdapat di Kecamatan Rancaekek seluas 2.126,95 Ha, dan selanjutnya di Kecamatan Blubur Limbangan seluas 1.930 Ha. Dari keseluruhan luas penggunaan lahan yang ada di DAS Citarik berdasrakan kegunaanya jumlah yang terbesar ada di areal persawahan sebesar 10.702,89 Ha, kemudian di ikuti oleh lahan berpengairan teknis sebesar 5.957,51 Ha, luas lahan non sawah sebesar 4.921,2 Ha, luas lahan tidak berpengairan sebesar 3.365,53 Ha dan luas lahan berpengairan non teknis sebesar 2.748 Ha. Selain itu berdasarkan peta tata guna lahan yang telah diuraikan berikut ini persentase luas lahan untuk masing-masing kecamatan yang masuk ke DAS Citarik. Selengkapnya dapat dilihat pada Tabel 4. Gambar 1 menyajikan peta segmentasi administrasi DAS Citarik.

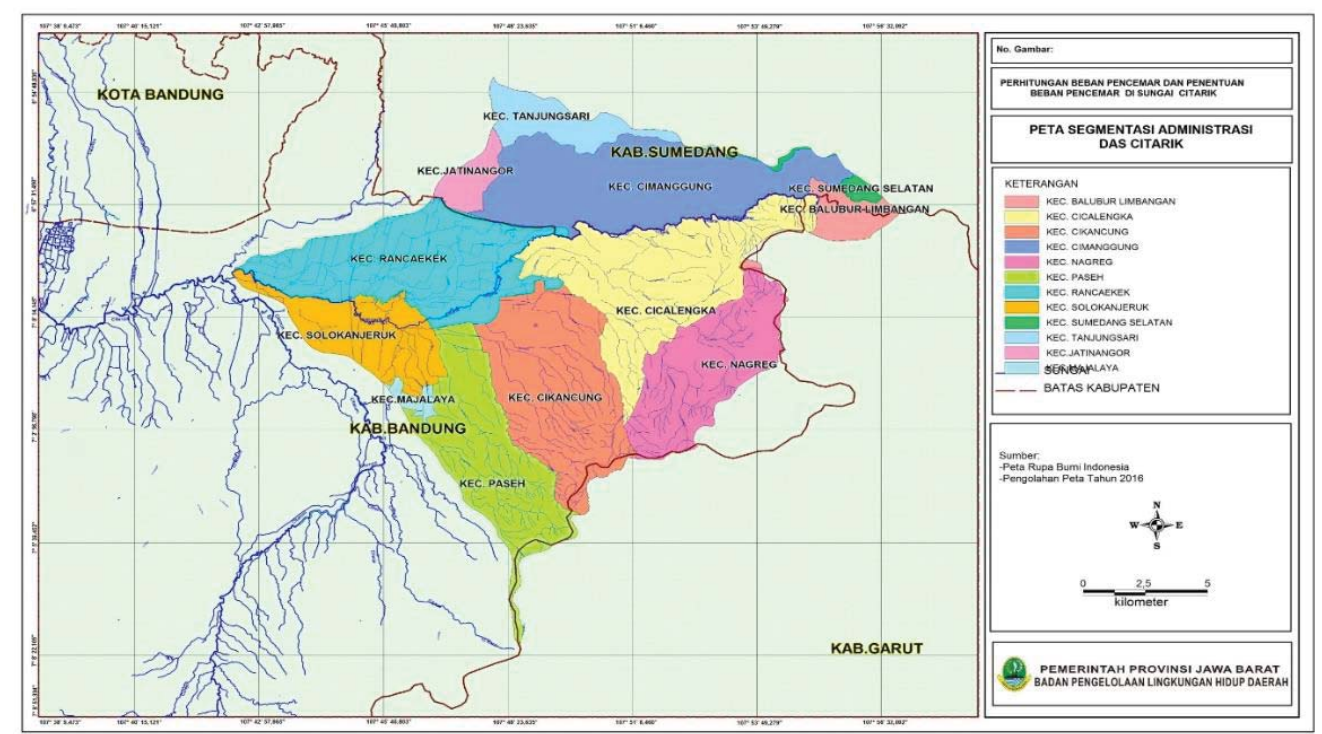

Gambar 1. Peta Segmentasi Administrasi DAS Citarik

Berdasarkan Tabel 4, dapat dilihat bahwa ada 2 kecamatan yang wilayah keseluruhannya masuk ke DAS Citarik yaitu Kecamatan Cikancung Kabupaten Bandung dan Kecamatan Cicalengka Kabupaten Bandung. Sedangkan untuk wilayah yang paling sedikit masuk ke dalam DAS Citarik yaitu Kecamatan Majalaya Kabupaten Bandung dengan prosentase $7 \%$ dari keseluruhan wilayah, dan Kecamatan Blubur Limbangan Kabupaten Garut dengan prosentase $9 \%$ dari keseluruhan wilayah.

Tabel 4. Lahan Lahan di DAS Citarik [1]

\begin{tabular}{ccccc}
\hline No & Kecamatan & $\begin{array}{c}\text { Luas Total Wilayah } \\
(\mathbf{H a})\end{array}$ & $\begin{array}{c}\text { Luas Wilayah yang Masuk } \\
\text { DAS Citarik } \\
(\text { Ha) }\end{array}$ & $\begin{array}{c}\text { Presentase } \\
(\mathbf{\%})\end{array}$ \\
\hline & Kabupaten Bandung & & 86 \\
\hline 1 & Paseh & 4.822 & 4.151 & 100 \\
\hline 2 & Cikancung & 3.866 & 3.866 & 100 \\
\hline 3 & Cicalengka & 3.978 & 3.978 & 87 \\
\hline 4 & Rancaekek & 4.503 & 3.916 & 78 \\
\hline 5 & Solokan Jeruk & 2.407 & 1.869 & \\
\hline
\end{tabular}




\begin{tabular}{ccccc}
\hline No & Kecamatan & $\begin{array}{c}\text { Luas Total Wilayah } \\
(\mathbf{H a})\end{array}$ & $\begin{array}{c}\text { Luas Wilayah yang Masuk } \\
\text { DAS Citarik } \\
(\mathbf{H a})\end{array}$ & $\begin{array}{c}\text { Presentase } \\
\mathbf{( \% )}\end{array}$ \\
\hline 6 & Nagreg & 4.198 & 2.724 & 65 \\
\hline 7 & Majalaya & 2.541 & 173 & 7 \\
\hline & & Kabupaten Sumedang & 19 \\
\hline 8 & Jatinangor & 2.620 & 486 & 23 \\
\hline 9 & Tanjungsari & 4.472 & 1.008 & 97 \\
\hline 10 & Cimanggung & 4.421 & 4.309 & 9 \\
\hline 11 & Blubur Limbangan & Kabupaten Garut & 629 \\
\hline
\end{tabular}

\subsection{Analisis Kualitas Air Sungai Citarik}

Berdasarkan hasil analisis laboratorium terdapat beberapa parameter yang tidak memenuhi baku mutu yang telah di tetapkan oleh Peraturan Pemerintah Nomor 82 Tahun 2001 [2] tentang Pengelolaan Kualitas Air dan Pengelolaan Pengendalian Air antara lain dapat dilihat pada Tabel 5.

Tabel 5. Parameter Yang Melebihi Baku Mutu

\begin{tabular}{|c|c|}
\hline Lokasi Sampling & Parameter \\
\hline 1 & $\mathrm{BOD}_{5}$, Sulfida, Detergen MBAS, Total Colli dan Fecal Colli. \\
\hline 2 & $\mathrm{BOD}_{5}$, Krom heksavalen, Nitrit, Klorin Bebas, Sulfida, Total Coli dan Fecal Coli. \\
\hline 3 & $\mathrm{BOD}_{5}$, Nitrit, Klorin Bebas, Detergen MBAS, Sulfida, Total Coli dan Fecal Coli. \\
\hline 4 & $\begin{array}{l}\mathrm{BOD}_{5}, \mathrm{COD}, \mathrm{DO}, \text { Timbal, Nitrit, Klorin Bebas, Detergen MBAS, Total Coli dan } \\
\text { Fecal Coli. }\end{array}$ \\
\hline 5 & $\begin{array}{c}\mathrm{BOD}_{5}, \mathrm{COD}, \mathrm{DO}, \text { Nitrat, Krom heksavalen, Tembaga, Nitrit, Klorin Bebas, Sulfida, } \\
\text { Detergen MBAS, Total Coli dan Fecal Coli. }\end{array}$ \\
\hline
\end{tabular}

Kondisi status mutu Sungai Citarik berdasarkan Metode Indeks Pencemaran menurut Keputusan Menteri Lingkungan Hidup Nomor 115 Tahun 2003 yang terjadi mulai dari hulu sampai dengan bagian tengah masuk ke dalam katagori cemar sedang, kemudian pada bagian hilir masuk dalam katagori cemar berat. Hal ini dikarenakan terjadinya akumulasi beban pencemar di bagian hilir. Sumber pencemar yang masuk limbah domestik yang pada umumnya dibuang secara langsung ke Sungai Citarik yakni berupa limbah padat dan limbah cair dari buangan rumah tangga, dan daerah industri, seperti sampah baik organik maupun non organik. Tabel 6 menjabarkan nilai IP di DAS Citarik.

Tabel 6. Nilai Indeks Pencemaran di DAS Citarik

\begin{tabular}{ccc}
\hline Lokasi Sampling & Nilai Indeks & Katagori \\
\hline 1 & 6 & Cemar Sedang \\
\hline 2 & 7 & Cemar Sedang \\
\hline 3 & 9 & Cemar Sedang \\
\hline 4 & 8 & Cemar Sedang \\
\hline 5 & 14 & Cemar Berat \\
\hline
\end{tabular}

Berdasarkan perhitungan kontribusi tiap kelompok parameter terhadap IP Air Sungai Citarik, menunjukkan bahwa lokasi sampling 1 parameter zat lainnya memberikan kontribusi terbesar yaitu $34,3 \%$ terhadap nilai IP, disusul parameter mikrobiologi sebesar 31,1\% dan Toksik (MBAS,Fenol Minyak dan Lemak, $\mathrm{CN}, \mathrm{Cl}_{2}$ ) $24,5 \%$. Hal ini menunjukkan bahwa pencemar zat lain yang berasal dari alami menjadi penyumbang terbesar terhadap nilai IP. Perhitungan kontribusi nilai kelompok parameter terhadap nilai IP tersebut sangat berguna bagi upaya pengendalian pencemaran air. Lokasi sampling 2 menunjukkan bahwa lokasi Citarik tengah parameter Toksik (MBAS, Fenol, Minyak dan Lemak, $\mathrm{CN}$, serta $\mathrm{Cl}_{2}$ ) memberikan kontribusi terbesar yaitu $30,7 \%$ terhadap nilai IP, disusul parameter zat lain 26,0\%, parameter mikrobiologi sebesar 23,4\%, organik $16,5 \%$ dan logam 3,4\%. Hal ini menunjukkan bahwa parameter toksik yang berasal dari limbah industry dan pertanian menjadi penyumbang terbesar terhadap nilai IP di Sungai Citarik tengah. 
Berdasarkan hasil perhitungan kontribusi tiap kelompok parameter terhadap nilai IP Sungai Citarik Sapan (hilir), parameter Toksit (MBAS, Fenol, Minyak dan Lemak, CN, serta $\mathrm{Cl}_{2}$ ) memberikan kontribusi terbesar yaitu sebesar $27,4 \%$, disusul parameter organik sebesar $24,2 \%$, zat lain $21 \%$ dan mikrobiologi sebesar 19,5\%. Berdasarkan perhitungan kontribusi tiap kelompok parameter terhadap nilai IP Sungai Cimande anak sungai Citarik, parameter Zat lain memberikan kontribusi terbesar yaitu $40,0 \%$ terhadap nilai IP, disusul parameter organik $25,4 \%$, zat lain sebesar 20,9\%, parameter Toksik (MBAS, Fenol, Minyak dan Lemak, $\mathrm{CN}$, serta $\mathrm{Cl}_{2}$ ) sebesar $11,4 \%$ dan logam relatif rendah. Hal ini menunjukkan bahwa pencemar zat lain yang berasal dari sumber alami menjadi penyumbang terbesar terhadap nilai IP. Berdasarkan perhitungan kontribusi tiap kelompok parameter terhadap nilai IP di lokasi Sungai Cikijing Jembatan Jalan Rancakekek, parameter toksik (MBAS, Fenol, Minyak dan Lemak, $\mathrm{CN}$, serta $\mathrm{Cl}_{2}$ ) memberikan kontribusi terbesar yaitu $42,6 \%$ terhadap nilai IP, disusul parameter organik 20,7\%, zat lain sebesar $19,0 \%$ mikrobiologi $10,5 \%$ dan logam sebesar $7 \%$. Gambar 2 sampai dengan 6 menyajikan grafik kontribusi masing-masing pencemar di Sungai Citarik.

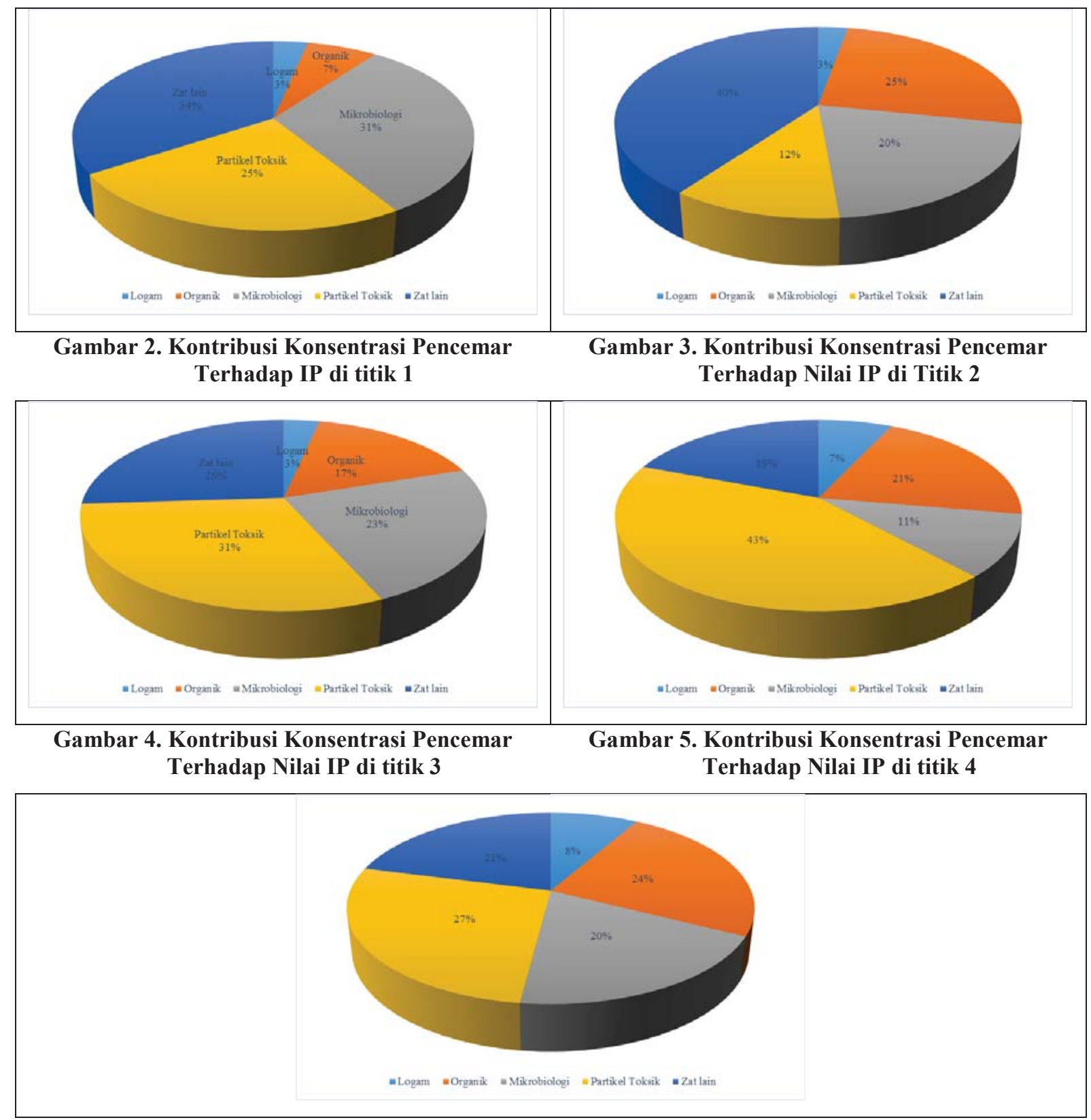

Gambar 6. Kontribusi Konsentrasi Pencemar Terhadap IP di titik 5 
Beban pencemaran air yang berada atau terangkut aliran Sungai Citarik dihitung dari hasil pengukuran debit air dan kadar parameter pencemaran air hasil pemantauan pada musim kemarau tahun 2016. Perhitungan beban pencemaran air dan beban pencemaran maksimum pada Sungai Citarik tersebut sebagai hasil pemantauan kualitas air dan debit air dinyatakan dengan parameter indikator BOD dan COD. Berdasarkan hasil perhitungan terlihat bahwa daya tampung beban pencemaran air Sungai Citarik untuk parameter BOD dan COD sudah jauh terlampaui. Hasil perhitungan daya tampung beban pencemaran air BOD dan COD disajikan pada Gambar 7 dan 8.

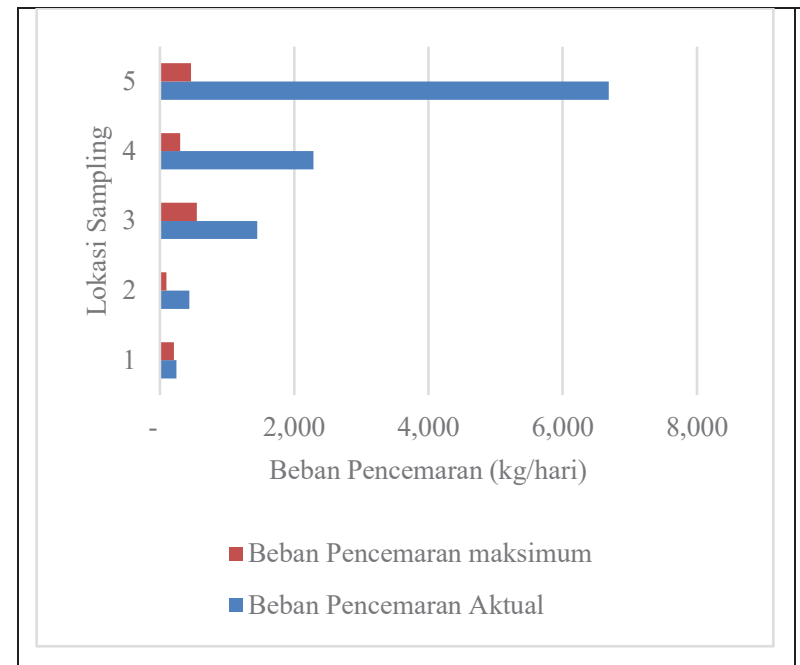

Gambar 7. BPA dan BPM Parameter BOD Sungai Citarik

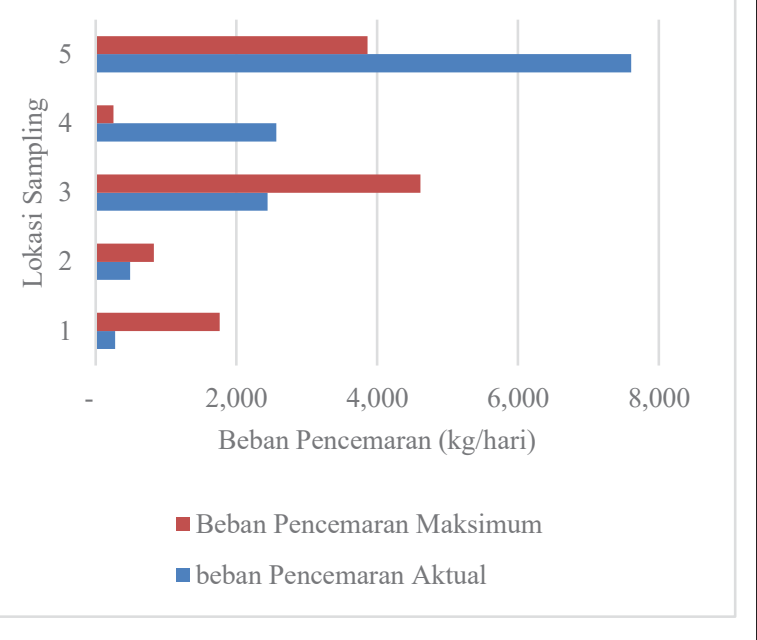

Gambar 8. BPA dan BPM Parameter COD Sungai Citarik

Berdasarkan Gambar 7 dan 8 terlihat bahwa lokasi 1 yang berada di dekat tempat Wisata Aki Enin nilai BOD mencapai $247 \mathrm{~kg} /$ hari dan COD adalah $274 \mathrm{~kg} /$ hari, lokasi 2 yang berada di dekat Mesjid Al Asstro nilai BOD mencapai $438 \mathrm{~kg} /$ hari dan COD adalah 491 ton/tahun, lokasi 3 di Haur Pugur nilai BOD mencapai $1.448 \mathrm{~kg} / \mathrm{hari}$ dan COD adalah $2.444 \mathrm{~kg} /$ hari, lokasi 4 di Jembatan Citarik II nilai BOD mencapai $2.287 \mathrm{~kg} /$ hari dan COD adalah $2.568 \mathrm{~kg} /$ hari, dan lokasi 5 di Jembatan Sapan-Citarik nilai BOD mencapai $6.686 \mathrm{~kg} /$ hari dan COD adalah $7.607 \mathrm{~kg} /$ hari. Berdasarkan Gambar 7 terlihat bahwa beban pencemaran maksimum untuk parameter BOD telah terlampau di semua titik. Berdasarkan Gambar 8 beban pencemaran maksimum parameter COD telah dilampaui pada titik 4 dan 5. Tabel 7 menyajikan debit, konsentrasi dan DTBPA Sungai Citarik, dimana berdasarkan tabel tersebut terlihat bahwa nilai negatif menunjukkan beban pencemaran yang harus diturunkan untuk parameter BOD dan COD supaya beban pencemaran maksimumnya tidak terlewati.

Tabel 7. Debit, Konsentrasi dan DTBPA Sungai Citarik

\begin{tabular}{cccccc}
\hline \multirow{2}{*}{ Lokasi } & $\begin{array}{c}\text { Debit air } \\
\left(\mathbf{m}^{\mathbf{3}} / \mathbf{d e t i k}\right)\end{array}$ & \multicolumn{2}{c}{ Konsentrasi $(\mathbf{m g} / \mathbf{L})$} & \multicolumn{2}{c}{ DTBPA (kg/hari) } \\
\cline { 3 - 6 } & 0,816 & BOD & COD & BOD & COD \\
\hline 1 & 0,383 & 13.25 & 3.89 & -35 & 1,489 \\
\hline 2 & 2,135 & 7.85 & 13.83 & -339 & 336 \\
\hline 3 & 1,162 & 22.78 & 25.59 & $-1,986$ & $-2,168$ \\
\hline 4 & 1,788 & 43.28 & 49.24 & $-6,223$ & $-3,745$ \\
\hline 5 & & & & &
\end{tabular}

Upaya pengendalian pencemaran BOD dan COD yang direncanakan oleh pemerintah untuk menurunkan beban pencemaran BOD dan COD antara lain: pengendalian pencemaran industri, pengendalian pencemaran limbah domestik (pembangunan IPAL Komunal, tangki septik, dan sistem perpipaan), pengendalian limbah pertanian, pertanian dan sampah domestik. Berdasarkan data dari buku putih sanitasi Kabupaten Bandung jumlah rumah tangga yang menggunakan tanki septik sebanyak 37,27\%. Di Kabupaten Bandung terdapat IPAL domestik yang terletak di Soreang, IPLT Babakan-Ciparay dan IPLT Majalaya, yang fungsinya kurang optimal. Langkah untuk mengurangi potensi beban pencemar dari sector domestik yaitu: (1) melanjutkan program yang berjalan, yaitu: 
Penerapan STBM (Sanitasi Total Berbasis Masyarakat), dan penyediaan sarana sanitasi komunal bagi masyarakat miskin dan (2) Penyusunan Master Plan IPAL Komunal.

Sungai Citarik ada indikasi pencemaran sejak di hulu oleh limbah ternak, Potensi beban pencemaran tertinggi limbah ternak terdapat di kecamatan Cikancung, terutama limbah ternak sapi. Langkah untuk mengurangi potensi beban pencemar dari sektor peternakan yaitu: (1) pengembangan IPAL limbah ternak, biogas dan pupuk kompos; (2) pengembangan dan Kordinasi Kelembagaan Pemerintah dan Pemberdayaan Masyarakat/LSM serta perusahaan swasta bidang pengadaan bibit pupuk pakan ternak; (3) pengembangan bio energi: pembangunan instalasi biogas; (4) penataan Kawasan Peternakan; dan (5) pengolahan limbah peternakan.

Sungai Citarik sudah tercemar oleh berbagai sumber limbah, termasuk limbah industri. Parameter zat toksik penyebab tingkat pencemaran berat berasal dari air limbah industri. Langkah untuk mengurangi potensi beban pencemar dari sektor industri yaitu: (1) industri baru dan pengembangan kapasitas industri lama yang membuang air limbah tidak diizinkan, karena Sungai Citarik yang tercemar berat; (2) kewajiban daur ulang air limbah industri dengan debit > 10 Liter/detik; (3) pembangunan sistem saluran kolektor gabungan air limbah zone industri, sehingga pembuangannya ke sungai terkendali dan terawasi; dan (4) melakukan revisi baku mutu alr limbah (BMAL), agar mengurangi beban pencemaran dan penambahan parameter BMAL sesuai proses industri.

\section{KESIMPULAN}

Perhitungan daya tampung beban pencemaran Sungai Citarik di DAS Citarik yang berada di 3 kabupaten yaitu Kabupaten Bandung, Sumedang, dan Garut menunjukkan bahwa kualitas air Sungai Citarik telah tercemar hal ini terlihat dari beberapa parameter seperti: TDS, TSS, BOD, COD, DO, Nitrat, Krom heksavalen, Tembaga, Nitrit, Klorin Bebas, Sulfida, Detergen MBAS, Total Colli dan Fecal Coli yang tidak memenuhi baku mutu. Ditinjau dari status mutu air Sungai Citarik termasuk katagori tercemar sedang sampai dengan berat. Kehadiran beberapa jenis logam berat di Sungai Citarik harus diwaspadai mengingat sifat dari logam yang, persistent, toksik, dan bersifat bioakumulasi. Berdasarkan hasil perhitungan terlihat bahwa daya tampung beban pencemaran air Sungai Citarik untuk parameter BOD dan COD sudah jauh terlampaui.

\section{DAFTAR PUSTAKA}

[1] Dinas Lingkungan Hidup (DLH) Kabupaten Bandung. 2016. Laporan Pemantauan Kualitas Lingkungan Kabupaten Bandung, Sumedang, dan Garut.

[2] Peraturan Pemerintah Nomor 82 Tahun 2001. Pengelolaan Kualitas Air dan Pengendalian Pencemaran Air

[3] Keputusan Menteri Negara Lingkungan Hidup Nomor 110 Tahun 2003 tentang Pedoman Penetapan Daya Tampung Beban Pencemaran Air Pada Sumber Air.

[4] Direktorat Pengembangan Penyehatan Lingkungan Permukiman. 2011. Modul-2 Tata Cara Pengendalian dan Pengawasa Pembangunan prasarnan air limbah sistem setempat. Dirjen Cipta Karya Kementerian Pekerjaan Umum. Jakarta. 